\title{
Survival, growth and regeneration of forest species in mining areas in the Eastern Amazonia
}

Sobrevivência, crescimento e regeneração de espécies florestais em áreas mineradas na Amazônia Oriental

\author{
W. B. R. Martins ${ }^{1 *}$; W. dos S. Barros ${ }^{1}$; L. F. S. Dionisio ${ }^{2}$; T. G. Bezerra ${ }^{1}$; M. L. \\ dos Santos $^{3}$; G. C. Ferreira ${ }^{1}$; V. M. Barbosa ${ }^{4}$; F. de A. Oliveira ${ }^{1}$ \\ ${ }^{1}$ Instituto de Ciências Agrárias, Universidade Federal Rural da Amazônia, 66077-830, Belém-PA, Brasil \\ ${ }^{2}$ Universidade Estadual do Pará, 66087-310, Belém-PA, Brasil \\ ${ }^{3}$ Universidade de Brasília, Campus Universitário Darcy Ribeiro, 70910-900, Brasília-DF, Brasil \\ ${ }^{4}$ Departamento de Meio Ambiente, Mineração Paragominas/MPSA, 68625-140, Paragominas-PA, Brasil \\ *walmerbruno@gmail.com \\ (Recebido em 04 de abril de 2020; aceito em 02 de junho de 2020)
}

\begin{abstract}
Planting forest saplings is the most usual method for restoring areas degraded by mining. Therefore, the objective of this study was to evaluate the survival growth of planted forest species and spontaneous regeneration in post-bauxite mining areas. For this purpose, we sampled plots in recovery areas with ages ranging from five to nine years, in which the establishment, recruitment, mean annual increase in diameter and total height of the species were evaluated. The species were further classified for conservation status and origin. Of the 156 species found, 18 presented less than $25 \%$ of survival and were therefore not recommended for use in the areas, while another 22 planted species showed more than $55 \%$ survival, indicating that they can be used. Five species were registered with some threat level, another nine species were registered as exotic to Brazil and four to the Amazon. In general, 35 species were classified as suitable for planting, with an acceptable mortality rate and satisfactory growth. Thus, it was possible to select those most suitable for planting the post mining area through an evaluation of the survival rate and growth of the species.

Keywords: Degraded areas, ecological restoration, selection of species.
\end{abstract}

O plantio de mudas florestais é o método mais usual para restauração das áreas degradadas pela mineração. Diante disso, o objetivo deste estudo foi avaliar a sobrevivência, o crescimento das espécies florestais plantadas e a regeneração espontânea em áreas pós mineração de bauxita. Para isso, instalamos parcelas em áreas em recuperação com idade entre cinco a nove anos, nas quais avaliou-se o estabelecimento, o recrutamento e o incremento médio anual tanto em diâmetro quanto em altura total das espécies. As espécies foram classificadas quanto ao status de conservação e a origem. De 156 espécies encontradas, 18 apresentaram menos de $25 \%$ de sobrevivência, sendo assim, não recomendadas para uso nas áreas e outras 22 espécies plantadas apresentaram mais de $55 \%$ de sobrevivência, indicando que podem ser utilizadas. Cinco espécies foram registradas com algum nível de ameaça, outras nove espécies foram registradas como exóticas para o Brasil e quatro para a Amazônia. No geral, 35 espécies foram classificadas como aptas ao plantio, com taxa de mortalidade aceitável e crescimento considerado satisfatório. Assim, por meio da avaliação da taxa de sobrevivência e crescimento das espécies, foi possível selecionar aquelas mais aptas ao plantio de área pós mineração.

Palavras-chave: Áreas degradadas, restauração ecológica, seleção de espécies.

\section{INTRODUCTION}

The Brazilian Amazon region is the third largest bauxite ore reserve in the world, with the state of Pará being the main producer of this raw material to obtain aluminium with $90.9 \%$ of the national production in 2014 [7]. Mineração Rio do Norte, Norsk Hydro and Alcoa are the main companies that exploit bauxite in Pará, which together contribute an average of $25 \%$ of the GDP (Gross Domestic Product) of the municipalities of Oriximiná, Paragominas and Juruti, generating a large contingent of direct and indirect jobs [1].

The bauxite extraction process to obtain aluminium in Brazil comprises the following phases: a) total vegetation suppression (shallow cut); b) topsoil removal; c) soil removal; d) removal of sterile 
material which does not present any economic use for the company; and e) separation of the bauxite from the tailings [26]. After these activities, topographic terrain reconditioning is conducted with subsequent spreading of the previously removed topsoil throughout the superficial soil layer, and then proceeding to restore the degraded areas according to the recovery plan of degraded areas (PRAD) of the company.

Returning the topsoil after the mining is essential, since it potentiates the natural regeneration due to the great quantity of seeds of forest species [23, 27] and improves the physical, chemical and microbiological properties of the soil [10]. The most commonly used method for forest restoration of areas degraded by mining is to plant seedlings of forest species associated with topsoil soil cover $[18,27]$, since these areas present low or no resilience after mineral extraction, especially when the sources of propagules are far from the areas to be restored. However, besides being costly, this method coupled with a high mortality rate of seedlings in the early years in mined areas many times does not guarantee project success [18].

Associated with these problems, the lack of seedlings of different native forest species for planting has become frequent [30]. This is because the seeds of some species present low viability and germination difficulties in nurseries [21], which may be the determining factor for the high mortality rates recorded in the field, especially in the early years where some species present up to one hundred percent mortality [27]. The mortality of seedlings not only increases the restoration cost, but also can expose the soil, which can lead to an erosive process. However, this obstacle can be minimized with the correct selection of species for restoration, considering their adaptability, information on rapid growth [34], production of resources to attract wildlife [4] and high litter production $[24,33]$ for soil cover. In addition, it should also be considered that a total modification of the environment will provide micro sites which are totally different from those prior to suppression, and that these environments may favour a particular group of species [9].

Thus, it is necessary that the selection and planting of species consider information about establishment and growth in sites near the mined areas, increasing the chance of survival of the seedlings after planting, thereby reducing the implementation costs. For this reason, continuous monitoring of the performance of planted species and natural regeneration in mining areas [3] is fundamental. It is possible to diagnose species adaptation, survival and growth through monitoring data, and then use this information to establish groups with similar growth characteristics and suitability for initial implantation $[9,27]$.

In this context, we aimed evaluate the survival, growth and entrance of naturally regenerating forest species after planting in bauxite mining areas in the Eastern Amazon.

\section{MATERIAL AND METHODS}

\subsection{Study area}

The study was developed in areas of the Mineração Paragominas S.A. company of the Hydro group, located in the northeast of the state of Pará, in Platô Miltônia 3 ( $\left.3^{\circ} 15^{\prime} 38^{\prime \prime S}, 47^{\circ} 43^{\prime} 28^{\prime \prime W}\right)$ at an altitude of $150 \mathrm{~m}, 70 \mathrm{~km}$ from the municipal headquarters of Paragominas-PA.

The predominant vegetation is classified as Submontane Dense Ombrophylous Forest [13] and the main soils are characterized as Yellow Latosols, Yellow Argisols, Plinthsols, Gleysols and Neosols [25]. The climate in the region is "Aw" (tropical humid) according to the Köppen-Geiser classification, and the average temperature is $26.3^{\circ} \mathrm{C}$ with annual rainfall of approximately 1,800 $\mathrm{mm}$, with the rainy season occurring from January to May with relative air humidity around $81 \%$ [2].

\subsection{Study ecosystem}

For selecting the species, we chose five areas under recovery with different years of implantation from 2009 to 2013 were selected (Table 1). A method of planting seedlings of native forest species with an average of 147 species was used in all areas, adopting spacing of $3 \times 3 \mathrm{~m}(1,111$ seedlings.ha ${ }^{-1}$ ). The number of individuals per species was different, as the number of seedlings per 
species varied according to the practicality of production, availability of seeds and also the absence of operational control at the time of planting.

Table 1: Number of plots and subplots for evaluating tree, shrub and regenerating individuals in the forest restoration plantation areas of previously mined areas, Paragominas, Pará, Brazil.

\begin{tabular}{ccccc}
\hline $\begin{array}{c}\text { Areas } \\
\text { studied }\end{array}$ & $\begin{array}{c}\text { Planting } \\
\text { year }\end{array}$ & $\begin{array}{c}\text { Year after } \\
\text { planting }\end{array}$ & $\begin{array}{c}\text { Size of the } \\
\text { studied areas (ha) }\end{array}$ & $\begin{array}{c}\text { Plots/ } \\
\text { subplots }\end{array}$ \\
\hline 1 & 2009 & 9 & 71.03 & $6 / 6$ \\
2 & 2010 & 8 & 61.69 & $6 / 6$ \\
3 & 2011 & 7 & 123.23 & $12 / 12$ \\
4 & 2012 & 6 & 74.75 & $6 / 6$ \\
5 & 2013 & 5 & 99.10 & $10 / 10$ \\
\hline Total & --- & --- & 429.80 & $40 / 40$ \\
\hline
\end{tabular}

The following procedures were performed in all areas prior to planting seedlings: a) reconditioning the terrain; $b$ ) subsoiling with application of natural reactive phosphate (33\% total $\mathrm{P}_{2} \mathrm{O}_{5}$ and $10 \% \mathrm{P}_{2} \mathrm{O}_{5}$ soluble in citric acid 2\%) at the bottom of the groove; and c) topsoil spreading. Then, $800 \mathrm{~kg} \mathrm{ha}^{-1}$ of dolomitic limestone was applied over the total area and $200 \mathrm{~g}$ of NPK fertilizer (06 30 06) and micronutrients $(0.5 \% \mathrm{~B}, 0.5 \% \mathrm{Cu}, 0.5 \% \mathrm{Zn})$ were applied per pit. Additionally, 2.5 $\mathrm{kg}$ of organic compound were used per pit, consisting of vegetal soil, charred açaí pits, charred rice straw, tanned and ground chicken litter and tanned and ground sheep manure in the proportion of $20 \%$ of each component.

\subsection{Species sampling and classification system}

In order to quantify the individuals planted in the five areas, we installed plots of $40 \times 50 \mathrm{~m}$ $\left(1,000 \mathrm{~m}^{2}\right)$ with subplots of $10 \times 10 \mathrm{~m}\left(100 \mathrm{~m}^{2}\right)$ to evaluate the natural regeneration of tree and shrub individuals (Table 1). The number of plots is variable per year of implantation according to the total size of the reclaimed area.

\subsection{Identification of tree and shrub species}

The tree and shrub species were identified at the species level and tagged with aluminium plates. When it was not possible to identify the species in situ, plant material was collected for scientific determination in the Felisberto Camargo herbarium of the Federal Rural University of Amazonia (UFRA). Botanical samples were sought for all registered species to certify the adopted scientific determination. The scientific names were corrected by the portal Reflora - Flora do Brasil 2020 Algas, Fungos e Plantas (http://floradobrasil.jbrj.gov.br/) [12], adopting the APG IV classification system [5].

\subsection{Absolute density of planting and natural regeneration}

We calculated the absolute density (AD) of the individuals that were planted, and the natural regeneration by the ratio of the number of individuals by the area in which they were sampled [32] (Equation 1).

In which:

$$
\mathrm{AD}=\frac{\mathrm{N}}{\mathrm{A}}
$$

$\mathrm{AD}=$ Absolute density, number of individuals per hectare; $\mathrm{N}=$ Absolute number of sampled individuals; $\mathrm{A}=$ Sampled area in hectares.

\subsection{Classification of species according to conservation status and origin}

We classified the species according which conservation status $[14,20]$. Those that are exotic in Brazil and the Amazonia biome were also registered. 


\subsection{Mortality, recruitment and entrance}

Mortality of trees and shrubs of a given species was determined by dividing the number of dead individuals by the number of living individuals [32] (Equation 2).

$$
\mathrm{MR}_{\mathrm{i}(\%)}=\frac{\mathrm{n}_{\mathrm{i}}}{\mathrm{N}_{\mathrm{i}}} \times 100
$$

In which:

$\mathrm{MR}_{\mathrm{i}}(\%)=$ mortality rate between two evaluations; $\mathrm{n}_{\mathrm{i}}=$ number of dead trees and shrubs of the i species between two successive evaluations; $\mathrm{N}_{\mathrm{i}}=$ number of live trees and shrubs of the i species in the first evaluation.

In addition, we evaluated the recruitment and entrance of natural regeneration (Equation 3), with all areas being evaluated from May 2013 to November 2017, thus equating to 4.5 years of monitoring. For the recruitment, we considered the new individuals of a species which were already present in the area and the entrance of individuals of new species appearing [15].

$$
R R_{i(\%)}=\left[\left(A_{1}-A_{0}\right) \times\left(A_{0}+A_{1}\right)^{-1}\right] \times 100
$$

In which:

$\mathrm{RR}_{\mathrm{i}}(\%)=$ natural regeneration rate of recruitment and entrance; $\mathrm{A}_{0}=$ absolute abundance in the first sampling of the i species; $A_{1}=$ absolute abundance in the second sampling of the $i$ species.

\subsection{Increase in diameter and height}

The growth data are the results of semi-annual flora monitoring, from which we obtained the DBH values (Diameter at Breast Height, measured at $1.30 \mathrm{~m}$ from the soil level for individuals with stem height $>1.30 \mathrm{~m}$ ), and/or stem diameter at $0.10 \mathrm{~m}$ from the soil (for individuals with stem height $\leq 1.30 \mathrm{~m})$ and total plant height $\left(\mathrm{H}_{\mathrm{t}}\right)$. The DBH was measured with a tape measure and the height using a measuring stick graduated in centimeters of $4 \mathrm{~m}$ in size. The last measurement of the growth variables was performed in November of 2017 and the obtained values were then used to calculate the Mean Annual Increase (MAI) in DBH and height (Equation 4 and 5 respectively).

$$
\begin{aligned}
\mathrm{MAI}_{\mathrm{DBH}} & =\frac{\mathrm{DBH}}{\mathrm{t}} \\
\mathrm{MAI}_{\mathrm{H}} & =\frac{\mathrm{H}_{\mathrm{t}}}{\mathrm{t}}
\end{aligned}
$$

In which:

MAI = Mean Annual Increase $(\mathrm{cm}) ; \mathrm{t}=$ Time (years); DBH $=$ Diameter at Breast Height $(\mathrm{cm})$; $\mathrm{H}_{\mathrm{t}}=$ Total height $(\mathrm{m})$.

\subsection{Classification of species in terms of planting suitability}

We categorized planted species and natural regeneration into four mortality classes [27], in which the mortality of a species could: a) very low - when the mortality rate is lower than the relative value of the mortality mean of all species sampled subtracted from the standard deviation; b) low - relative mortality below or equal to the mean and equal to or above the upper limit of the very low class; c) high - relative mortality above the mean and equal to or below the lower limit of the very high class; and d) very high - relative mortality above the sum of the mean plus standard deviation. We excluded exotic species from Brazil from this classification, as well as those which obtained a total of less than five individuals, providing a higher reliability of the evaluations. We 
also categorized the $\mathrm{MAI}_{\mathrm{DBH}}$ and $\mathrm{MAI}_{\mathrm{H}}$ of each species into four classes: a) very low; b) low; c) high; and d) very high, following the same criteria used in the mortality description.

The survival rate is considered the variable of greater interest in relation to the MAI, since some species present slow growth in relation to others. For this reason we attributed weights to the variables, with mortality receiving a weight of 2 , and the $\mathrm{MAI}_{\mathrm{DBH}}$ and $\mathrm{MAI}_{\mathrm{H}}$ a weight of 1 . Thus, we classified the MAI as: "very low $=1$ ", "low $=2$ ", "high $=3$ ", "very high $=4$ ". The values with a weight of 2 for the mortality rate: "very high $=2$ ", "high $=4$ ", "low $=6$ " and "very low $=8$ ". We calculated the weighted value by the sum of the values assigned to each variable, and the higher the value, the better the performance of the species and, therefore the more suitable it is for the initial planting.

Therefore, we classified the species considered suitable for planting, meaning with satisfactory performance, those with "very low" to "low" mortality rate and "very high", "high" and "low" MAI in diameter and height. We also considered the low category for MAI in diameter and height in virtue of two species to considerably raise the average value of these variables. In addition, some species show limited growth ecologically.

\section{RESULTS AND DISCUSSION}

\subsection{Planting density and natural regeneration}

In total, we found 125 species at the planting and 40 the natural regeneration, with 40 common species between the planting and the regeneration, therefore resulting in 156 species in general. Of these, the largest number of species was recorded in the area implanted in 2009, while the lowest in the area implanted in 2013 (Table 2).

Table 2: Number of planted and regenerating species considered alive and vegetation density in areas under restoration process previously degraded by mining activity in the municipality of Paragominas, Pará, Brazil.

\begin{tabular}{ccccccc}
\hline $\begin{array}{c}\text { Planting } \\
\text { year }\end{array}$ & $\begin{array}{c}\text { Restoration } \\
\text { time (years) }\end{array}$ & $\begin{array}{c}\text { Number of } \\
\text { plant species }\end{array}$ & $\begin{array}{c}\text { Density of } \\
\text { planting } \\
\text { (ind ha }{ }^{-1} \text { ) }\end{array}$ & $\begin{array}{c}\text { Number of } \\
\text { species } \\
\text { regenerating }\end{array}$ & $\begin{array}{c}\text { Density of } \\
\text { regenerating } \\
\text { (ind ha } \text { (n) }^{-1}\end{array}$ & $\begin{array}{c}\text { Density of } \\
\text { total } \\
\text { (ind ha }^{-1} \text { ) }\end{array}$ \\
\hline 2009 & 9 & 72 & 345.00 & 15 & 616.67 & 961.67 \\
2010 & 8 & 36 & 276.67 & 13 & 1316.67 & 1593.34 \\
2011 & 7 & 47 & 260.83 & 19 & 2183.33 & 2444.16 \\
2012 & 6 & 41 & 401.67 & 16 & 1500.00 & 1901.67 \\
2013 & 5 & 31 & 470.00 & 6 & 540.00 & 1010.00 \\
\hline
\end{tabular}

The absolute density of planted species was higher in the area with the shortest restoration time; in contrast, the number of regenerating species was small when compared to the other areas (Table 2). We also observed that there was no increase in the number of species in the natural regeneration with the advance of the restoration, which can be explained as a function of the topsoil storage time, which was possibly different between the areas. The topsoil storage time presents an inverse relationship with germination, because the seeds end up germinating early, being able to also die buried due to an absence of oxygen and still be preyed upon by microorganisms [11].

Of the five areas, those of seven and eight years presented the lowest densities of planted species. However, this low density was supplied by natural regeneration, especially in the area of seven years. This can be considered an indicator of the local vegetation reestablishing and consequently of the successional processes, beginning the stratification of a future forest [16].

\subsection{Conservation status of species}

Of the 156 species found in the five areas, six (3.85\%) presented some conservation status [14, 20] (Table 3). 
Table 3: Species with some conservation status and their respective numbers of individuals and mortality rate in areas under restoration process previously degraded by mining activity in the municipality of Paragominas, Pará, Brazil. NT: Nearly threatened; VU: Vulnerable; EN: Endangered; CR: Critically endangered; LC: Less concerning.

\begin{tabular}{|c|c|c|c|c|}
\hline \multirow[b]{2}{*}{ Species } & \multicolumn{2}{|c|}{ Threat level } & \multirow[b]{2}{*}{$\begin{array}{l}\text { Individuals } \\
\text { number }\end{array}$} & \multirow[b]{2}{*}{$\begin{array}{c}\text { Mortality } \\
\%\end{array}$} \\
\hline & $\begin{array}{l}\text { Martinelli \& } \\
\text { Moraes (2013) }\end{array}$ & $\begin{array}{l}\text { IUCN } \\
(2019)\end{array}$ & & \\
\hline Cedrela fissilis Vell. & VU & VU & 23 & 17,0 \\
\hline Amburana cearensis (Allemão) A.C. Sm. & NT & EN & 5 & 20,0 \\
\hline Hymenaea parvifolia Huber & VU & $\mathrm{LC}$ & 91 & 30,0 \\
\hline Vоиасароиа атегісапа Aubl. & EN & $\mathrm{CR}$ & 3 & 33,0 \\
\hline Swietenia macrophylla King & VU & VU & 57 & 51,0 \\
\hline Handroanthus impetiginosus (Mart. ex DC.) Mattos & NT & ---- & 36 & 83,0 \\
\hline
\end{tabular}

These species are considered important for conservation of the flora of the Amazonia biome and for this reason we suggest that they be planted initially or in the vegetation enrichment phase, except for Amburana cearensis (Allemão) A.C. Sm. which does not occur naturally in the north of Brazil, and Handroanthus impetiginosus (Mart. ex DC.) Mattos, which presented an elevated mortality percentage, and should therefore be planted as a vegetation enrichment strategy. Plantations which aim at conserving endangered species should be carried out near areas of natural occurrence, seeking to recompose natural populations and the germplasm bank [28].

\subsection{Exotic species}

We found nine species considered exotic for Brazil were found: Mangifera indica L., Annona muricata L., Cassia fistula L., Leucaena leucocephala (Lam.) de Wit, Tamarindus indica L., Pachira glabra Pasq., Khaya ivorensis A.Chev., Citharexylum macrophyllum Poir., and Anadenanthera pavonina L., as well as four exotic species for the Amazon biome: Amburana cearensis (Allemão) A.C. Sm., Bauhinia rufa (Bong.) Steud., Libidibia ferrea (Mart.) L.P.Queiroz and Stryphnodendron coriaceum Benth.

Exotic species are not recommended for restoring forest of degraded areas, as some of them may inhibit the growth and natural regeneration of native species or even occupy extensive areas, transforming the structure and consequently ecosystem functions. Among the exotic species in Brazil, Leucaena leucocephala is considered aggressive, inhibiting forest succession [29]. In addition to being exotic and invasive, Mangifera indica as well as L. leucocephala should be eradicated and are not recommended for implantation in other areas.

Regarding the exotic species of the Amazonian Biome, Libidibia ferrea appears in four of the five studied areas, with $95 \%$ survival (38 individuals), therefore constituting one of the species with the highest survival percentage, being adapted to the bio-edaphic climatic conditions of the region. This species is considered to be multipurpose and naturally occurs from Piauí to Rio de Janeiro [17], and is also recommended for restoring degraded areas in the state of Rio de Janeiro [22].

\subsection{Mortality, recruitment and entrance}

Species represented by more than four planted individuals presented a high mortality rate, reaching 100\%, such as Annona mucosa, Euterpe oleracea, Parkia gigantocarpa and Khaya ivorensis (Table 4). The initial planting of these species should be avoided, since the environmental conditions are not appropriate to their ecological characteristics. The high mortality rate exposes the soil to erosive processes, consequently promoting compaction and scarcity of initial organic matter [26]. In addition, it is important to consider intraspecific competition for resources, and those species that obtain better interaction with the environment tend to survive.

Schizolobium parahyba var. amazonicum and Bixa orellana were planted in the five evaluated areas, with 2,752 and 1,121 individuals respectively. These species have frequently been used because of the ease to obtain seeds and fast growth; however, the individuals of these species 
recorded an expressive mortality in this work rate (> 94\%) (Table 4), indicating that they should not be planted in similar features.

Table 4: Species with the highest mortality rates that were planted in areas previously degraded by bauxite mining in the municipality of Paragominas, Pará, Brazil.

\begin{tabular}{|c|c|c|c|}
\hline $\begin{array}{l}\text { Number of } \\
\text { occurring } \\
\text { areas }\end{array}$ & Species & $\begin{array}{l}\text { Mortality } \\
(\%)\end{array}$ & $\begin{array}{c}\text { Number of } \\
\text { Individuals } \\
\text { dead }\end{array}$ \\
\hline \multirow{3}{*}{5} & Bixa orellana $\mathrm{L}$. & 98.11 & 52 \\
\hline & Schizolobium parahyba var. amazonicum (Huber ex Ducke) Barneby & 94.20 & 65 \\
\hline & Handroanthus impetiginosus (Mart. ex DC.) Mattos & 83.33 & 30 \\
\hline \multirow{3}{*}{4} & Lecythis lurida (Miers) S.A.Mori & 89.47 & 17 \\
\hline & Mabea fistulifera Benth. & 78.95 & 15 \\
\hline & Ceiba pentandra (G.) Gaertn. & 76.92 & 30 \\
\hline \multirow[t]{2}{*}{3} & Annona mucosa Jacq. & 100.00 & 14 \\
\hline & Spondias mombin L. & 80.00 & 16 \\
\hline \multirow{6}{*}{2} & Euterpe oleracea Mart. & 100.00 & 4 \\
\hline & Parkia multijuga Benth. & 81.82 & 9 \\
\hline & Bagassa guianensis Huber & 81.25 & 13 \\
\hline & Mabea fistulifera Benth & 78.95 & 15 \\
\hline & Sterculia apetala var. elata (Ducke) E.L. Taylor ex Brako \& Zarucchi & 78.13 & 25 \\
\hline & Senna georgica H.S.Irwin \& Barneby var. georgica & 77.78 & 7 \\
\hline \multirow{4}{*}{1} & Parkia gigantocarpa Ducke & 100.00 & 5 \\
\hline & Khaya ivorensis A.Chev. & 100.00 & 5 \\
\hline & Bowdichia nitida Spruce ex Benth. & 88.00 & 15 \\
\hline & Citharexylum macrophyllum Poir. & 86.67 & 13 \\
\hline
\end{tabular}

Although S. parahyba var. amazonicum is a legume tree with an indication of microbiological association that promotes soil improvement, the obtained data indicate that its planting is not recommended in severely degraded areas, since the species has a tall and sparse crown [31], thus sparingly covering the soil and leaving it susceptible to breaking its stem in open areas. In addition, their seeds and fruits are not considered attractive to the wild fauna, which is an important characteristic that must be considered with the criterion for choosing the species.

Of the species we found at the regenerating, Trema micranta obtained a mortality rate of approximately 100\%, and Solanum species resulted in more than $80 \%$ (Figure 1). These species have substantial initial contribution to restoring environments through litter deposition which increases the amount of organic material and improves the soil fertility and then by dying, thereby fulfilling its cycle in the successional process. For these reasons, we suggest that topsoil be managed in such a way as to increase the natural regeneration of these species.

Some regenerating species presented a number of individuals higher than ten and occurred in three or more areas, including Croton matourensis with 228 live individuals $\left(0.53\right.$ ind ha $\left.^{-1}\right)$ and a survival rate of $68 \%$ after 4.5 years of monitoring. It is a species that produces litter in abundance, aiding in water retention capacity [19], soil protection and promotes soil fertility by the availability of nutrients.

Our results showed that, only three species from planting were established in the natural regeneration, namely: Handroanthus ochraceus (Cham.) Mattos, Handroanthus sp. and Byrsonima crassifolia $(\mathrm{L}$.) Kunth. were found in all the evaluated areas and is popularly known as murucizeiro. The fruits of this species serve as a food source for birds and large mammals which probably disperse the seeds in the most distant areas [8].

In total, 33 new species entered the five evaluated areas, of which $17(51.52 \%)$ entered the area seven years after implantation. From the incoming species, we contacted that five appear in all areas, namely: Solanum crinitum Lam., Solanum sp., Trema micrantha (L.) Blume, Vismia guianensis (Aubl.) Choisy and Croton matourensis Aubl. 


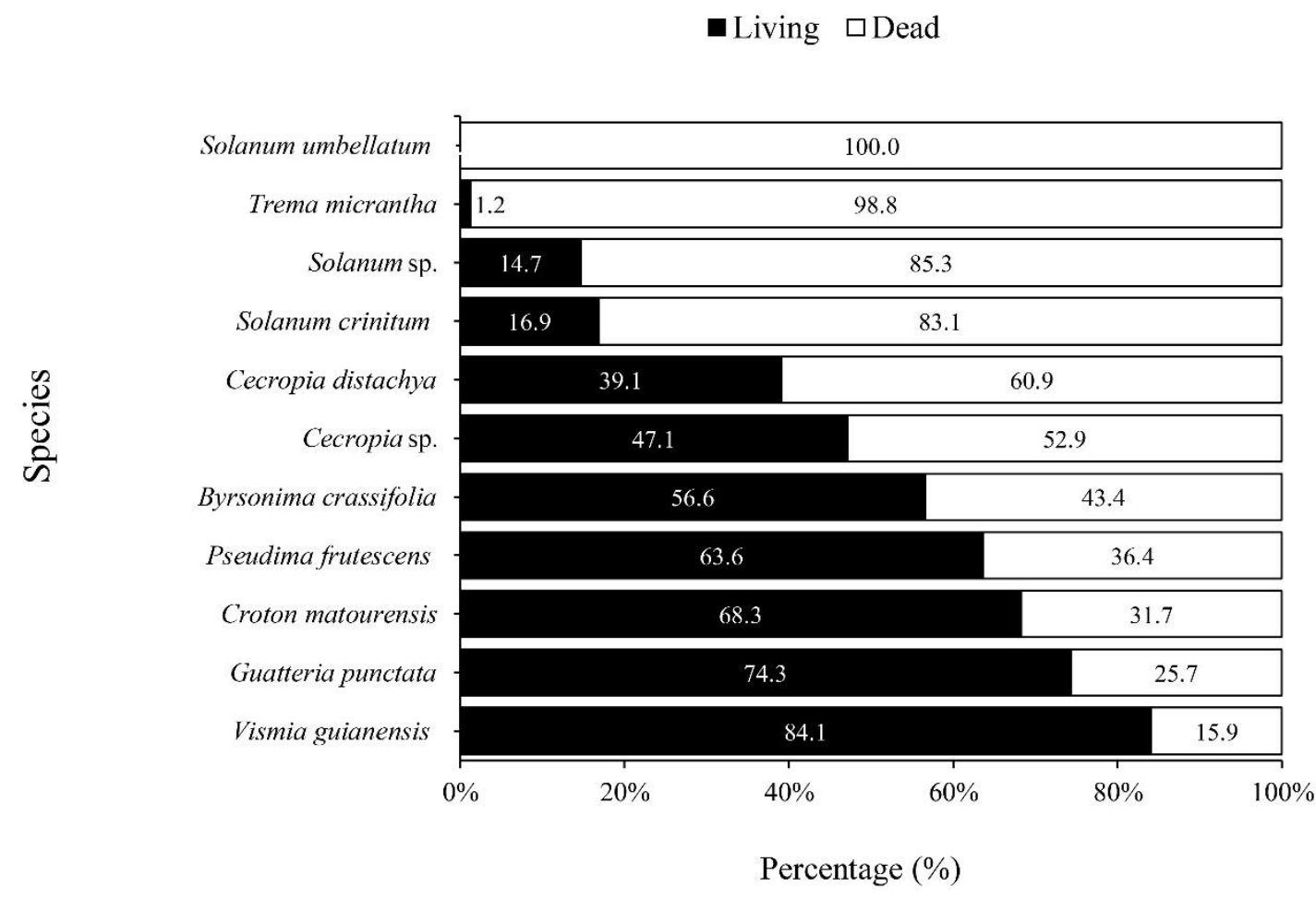

Figure 1: Rate of living and dead individuals of the main regenerating species that occurred in three or more areas under forest restoration process during 4.5 years of monitoring in the municipality of Paragominas, Pará, Brazil.

\subsection{Increase in diameter and height}

The average $\mathrm{MAI}_{\mathrm{DBH}}$ values varied from $1.20 \pm 0.99$ to $0.84 \pm 0.61 \mathrm{~cm} \mathrm{yr}^{-1}$ for the areas of nine and seven years of age, respectively (Figure 2). When analysed only the planted individuals, the average ranges from $0.94 \pm 0.46$ and $0.69 \pm 0.39 \mathrm{~cm} \mathrm{yr}^{-1}$. Even though it is smaller than in general, these values of the planted species are superior to the $0.48 \pm 0.41 \mathrm{~cm} \mathrm{yr}^{-1}$ found at Mineração Rio do Norte - MRN, in Oriximiná after 13 years [27].
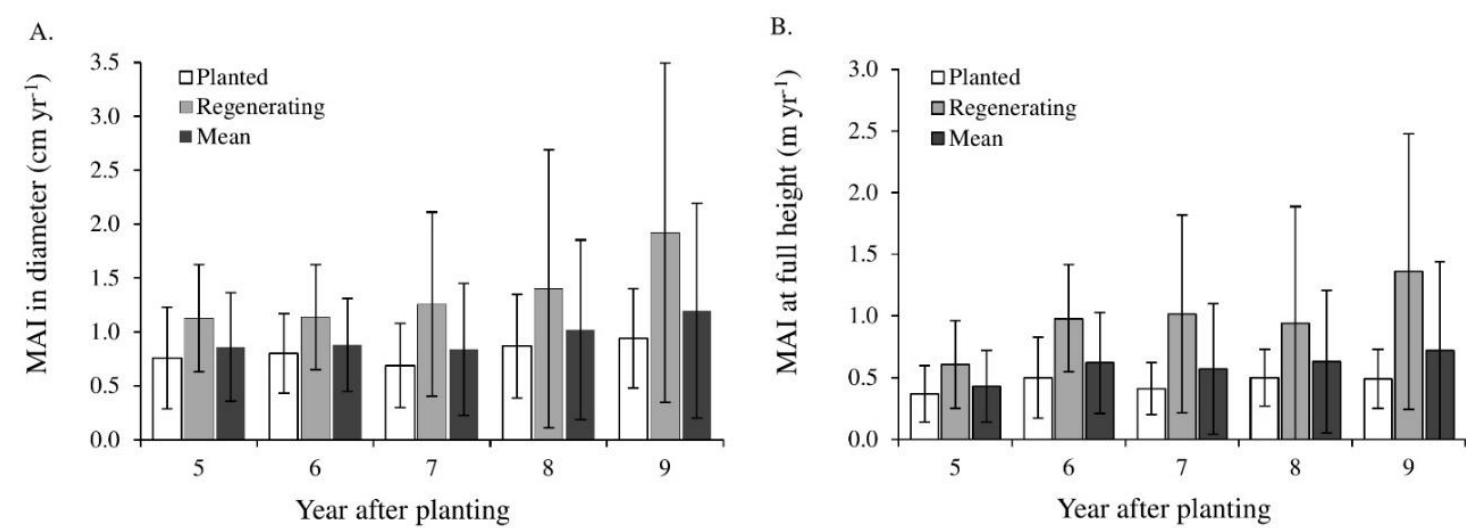

Figure 2: The mean annual increase in diameter $\left(M A I_{D B H}\right)$ and total height $\left(M A I_{H}\right)$ of the individuals that were planted and the regenerants in areas previously degraded by bauxite mining in the city of Paragominas, Pará, Brazil. Bars represent the average values followed by the standard deviation. 
We found that natural regeneration species present higher average values than planted species because these plants are already adapted in these areas with investment of their resources initially for height growth and later in diameter [6]. We also infer that lateral growth is usually accompanied by crown area growth, thereby covering the soil, and consequently protecting it against the elements.

Of the species with the highest survival rates, the $\mathrm{MAI}_{\mathrm{DBH}}$ and $\mathrm{MAI}_{\mathrm{H}}$ values were $0.83 \mathrm{~cm} \mathrm{yr}^{-1}$ and $0.49 \mathrm{~m} \mathrm{yr}^{-1}$, respectively, for 22 species (Table 5). Of these, Senegalia polyphylla was one of the species planted in the five areas, with a total of 155 individuals (Table 5). Despite this, we observed that there has not been natural regeneration under the canopy of this species, with the subforest practically without vegetation, thus proving to probably be allelopathic, and with detailed studies on this therefore being recommended.

Table 5: Species with the highest survival rates with respective mean annual increase in $D B H\left(M A I_{D B H}\right)$ and total height $\left(M A I_{H}\right)$, which were planted in areas previously degraded by bauxite mining in the municipality of Paragominas, Pará, Brazil.

\begin{tabular}{|c|c|c|c|c|}
\hline \multirow{2}{*}{$\begin{array}{c}\text { Number of } \\
\text { occurring } \\
\text { areas }\end{array}$} & \multirow{2}{*}{ Species } & \multirow{2}{*}{$\begin{array}{l}\text { Survival \% }\left(\mathrm{n}^{\circ}\right. \\
\text { individuals) }\end{array}$} & \multicolumn{2}{|c|}{ MAI } \\
\hline & & & $\mathrm{DBH}_{(\mathrm{cm})}$ & $\mathrm{H}_{(\mathrm{m})}$ \\
\hline \multirow{3}{*}{5} & Senegalia polyphylla (DC.) Britton \& Rose & $84(130)$ & 1.32 & 0.70 \\
\hline & Byrsonima crassifolia (L.) Kunth & $84(59)$ & 0.72 & 0.48 \\
\hline & Genipa americana $\mathrm{L}$. & $70(83)$ & 0.56 & 0.32 \\
\hline \multirow{3}{*}{4} & Libidibia ferrea (Mart. ex Tul.) L.P.Queiroz & $95(38)$ & 0.55 & 0.50 \\
\hline & Hymenaea parvifolia Huber & $70(64)$ & 0.76 & 0.43 \\
\hline & Bauhinia rufa (Bong.) Steud. & $68(17)$ & 0.71 & 0.40 \\
\hline \multirow{6}{*}{3} & Inga laurina (Sw.)Wild. & $100(15)$ & 0.57 & 0.40 \\
\hline & Cedrela fissilis Vell. & $83(19)$ & 0.85 & 0.57 \\
\hline & Inga alba (Sw.) Willd. & $67(12)$ & 0.98 & 0.57 \\
\hline & $\begin{array}{l}\text { Chamaecrista ensiformis var. plurifoliolata (Hoehne) } \\
\text { H.S.Irwin \& Barneby }\end{array}$ & $67(8)$ & 0.71 & 0.49 \\
\hline & Oenocarpus distichus Mart. & $63(5)$ & 0.93 & 0.24 \\
\hline & Andira inermis W.Wright & $60(15)$ & 0.52 & 0.38 \\
\hline \multirow{5}{*}{2} & Astronium lecointei Ducke & $100(7)$ & 0.78 & 0.45 \\
\hline & Guazuma ulmifolia Lam. & $100(5)$ & 1.20 & 0.81 \\
\hline & Clitoria arborea Benth. & 95 (19) & 0.87 & 0.59 \\
\hline & Chloroleucon acacioides (Ducke) Barneby \& J.W.Grimes & $80(8)$ & 0.83 & 0.53 \\
\hline & Anacardium occidentale L. & $66(15)$ & 0.78 & 0.34 \\
\hline \multirow{5}{*}{1} & Astronium graveolens Jacq. & $100(5)$ & 0.62 & 0.44 \\
\hline & Pseudobombax munguba (Mart. \& Zucc.) Dugand & $80(4)$ & 0.83 & 0.29 \\
\hline & Amburana cearensis (Allemão) A.C. Sm. & $80(4)$ & 0.46 & 0.35 \\
\hline & Machaerium froesii Rudd & $70(7)$ & 1.06 & 0.68 \\
\hline & Mimosa schomburgkii Benth. & $71(5)$ & 1.73 & 0.74 \\
\hline
\end{tabular}

There was more than $95 \%$ survival registered for Libidibia ferrea, Inga laurina, Astronium lecointei, Clitoria arborea, Guazuma ulmifolia, Astronium graveolens, Andira surinamensis, Hymenaea courbaril, and Chrysophyllum sparsiflorum (Table 5). However, except for L. ferrea and $C$. arborea, the absolute number of individuals for the other species was less than ten, with no guarantee that they will actually achieve satisfactory growth and adaptation performance.

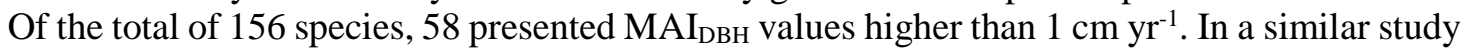
carried out in Oriximiná-PA, found only five species with a diametric increase superior to $1 \mathrm{~cm} \mathrm{yr}^{-}$

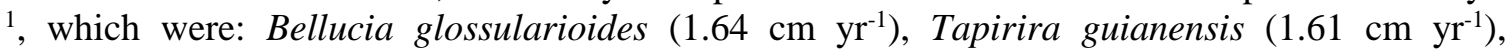
Simarouba amara $\left(1.24 \mathrm{~cm} \mathrm{yr}^{-1}\right)$, Stryphnodendron guianensis $\left(1.23 \mathrm{~cm} \mathrm{yr}^{-1}\right)$ and Anacardium occidentale $\left(1.111 \mathrm{~cm} \mathrm{yr}^{-1}\right)$ [27]. 


\subsection{Increase in diameter and height of regenerating species}

Of the regenerating species in the planting areas, five had more than ten individuals and a mortality rate of less than $50 \%$ and $\mathrm{MAI}_{\mathrm{DBH}}$ that ranged from 0.70 to $2.08 \mathrm{~cm} \mathrm{yr}^{-1}$ and $\mathrm{MAI}_{\mathrm{H}}$ from 0.67 to $1.41 \mathrm{~m} \mathrm{yr}^{-1}$ (Table 6). Three of these species occur in all evaluated areas, and Byrsonima crassifolia was recorded in planting and natural regeneration. The highest MAI values for Vismia guianensis and Croton matourensis were found in DBH and height, and the MAI value for $C$. matourenses is more than twice the mean value recorded for planted areas (Figure 2), and well higher than the mean values of the regenerating species, in which the MAI in diameter and height were respectively $1.37 \mathrm{~cm} \mathrm{yr}^{-1}$ and $0.98 \mathrm{~m} \mathrm{yr}^{-1}$.

In a fragment of secondary forest near our study area found $V$. guianensis and $C$. matourensis were as being among the ten most representative species, proving to be abundant in the seed bank and adapted to the local conditions [18].

Table 6: Absolute number and their respective mean annual increase values in diameter at breast height $\left(M A I_{D B H}\right)$ and total height $\left(M A I_{H}\right)$ for regenerating species (with ten or more individuals) of the planted areas with low-mortality (less than 50\%) in bauxite mining areas in Paragominas, Pará, Brazil.

\begin{tabular}{clccccc}
\hline $\begin{array}{c}\text { Number of areas } \\
\text { of planting }\end{array}$ & \multicolumn{1}{c}{ Species } & $\begin{array}{c}\text { Total number } \\
\text { individuals }\end{array}$ & $\begin{array}{c}\text { Individuals } \\
\text { dead }\end{array}$ & $\begin{array}{c}\text { Mortality } \\
\%\end{array}$ & \multicolumn{2}{c}{ MAI } \\
\hline 5 & Croton matourensis Aubl. & 334 & 106 & 33 & 2.08 & 1.41 \\
5 & Vismia guianensis (Aubl.) Choisy & 108 & 18 & 17 & 1.02 & 1.11 \\
5 & Byrsonima crassifolia (L.) Kunth & 53 & 23 & 43 & 0.85 & 0.90 \\
3 & Guatteria punctata (Aubl.) R.A.Howard & 28 & 6 & 21 & 0.81 & 0.76 \\
2 & Cheiloclinium sp. & 21 & 7 & 33 & 0.70 & 0.67 \\
\hline
\end{tabular}

\subsection{Species indicated for planting}

Of the total species we found with more than four individuals, $35(22.4 \%)$ species were considered suitable for planting in environments degraded by bauxite mining in sites with the same characteristics of the studied areas. These species were selected according to the highest weighted values (WV), calculated by the sum of the weights of mortality and MAI in diameter and total height (Table 7).

Very low (VL) and low (LO) mortality species recorded percentage values lower than $13.38 \%$ and between 13.38 and $51.57 \%$, respectively. Of the species we are indicating seven were classified in the class of "very low mortality", indicating high adaptability, and therefore they should be prioritized in future plantations with characteristics like the studied areas.

Values we considered high in relation to $\mathrm{MAI}_{\mathrm{DBH}}$ (greater than or equal to 1.04 and less than or equal to $1.85 \mathrm{~cm} \mathrm{yr}^{-1}$ ) were recorded for seven species, while only $C$. matourensis was classified as having a very high value (higher than $1.85 \mathrm{~cm} \mathrm{yr}^{-1}$ ), also presenting the largest $\mathrm{MAI}_{\mathrm{H}}$ with $1.41 \mathrm{~m}$ $\mathrm{yr}^{-1}$. Increasing values higher than the general average with high values of standard deviation led to few species being classified as having high to very high increases.

We note that species with unsatisfactory performance should not be totally excluded, especially those of the secondary or shade-tolerant ecological groups, but that their introduction in the areas is in a stepwise manner, meaning for enrichment activity after the initial planting.

Factors not directly associated with the species but which may directly affect their establishment in the areas should be jointly considered with the soil preparation and the appropriate period for planting, thereby guaranteeing survival rate and growth which ensure recovery of the areas. 
Table 7: Relation of the forest species considered suitable for planting according to a "low (LO)" to "very low (VL)" mortality rate and the mean annual increment in diameter at breast height $\left(M A I_{D B H}\right)$ and total height $\left(\mathrm{MAI}_{H}\right)$ "very high (VH)", "high (HI)" and "low (LO)" in areas that were previously degraded by bauxite mining in Paragominas, Pará, Brazil.

\begin{tabular}{|c|c|c|c|c|c|c|c|c|}
\hline \multirow{2}{*}{ Species } & \multirow{2}{*}{$\begin{array}{c}\text { Mortality } \\
\%\end{array}$} & \multirow{2}{*}{$\begin{array}{l}\mathrm{N}^{\circ} \mathrm{de} \\
\text { Ind. }\end{array}$} & \multicolumn{2}{|c|}{ MAI } & \multicolumn{3}{|c|}{ Performance proficiency } & \multirow{2}{*}{ WV } \\
\hline & & & $\mathrm{DBH}_{(\mathrm{cm})}$ & $\mathrm{H}_{(\mathrm{m})}$ & Mort. & MAIDBH & $\mathrm{MAI}_{\mathrm{H}}$ & \\
\hline Croton matourensis & 32.72 & 324 & 2.08 & 1.41 & $\mathrm{LO}^{(6)}$ & $\mathrm{VH}^{(4)}$ & $\mathrm{VH}^{(4)}$ & 14 \\
\hline Simarouba amara & 7.69 & 13 & 1.15 & 0.59 & $\mathrm{VL}^{(8)}$ & $\mathrm{HI}^{(3)}$ & $\mathrm{LO}^{(2)}$ & 13 \\
\hline Astronium lecointei & 0.00 & 7 & 0.78 & 0.45 & $\mathrm{VL}^{(8)}$ & $\mathrm{LO}^{(2)}$ & $\mathrm{LO}^{(2)}$ & 12 \\
\hline Inga laurina & 0.00 & 15 & 0.78 & 0.49 & $\mathrm{VL}^{(8)}$ & $\mathrm{LO}^{(2)}$ & $\mathrm{LO}^{(2)}$ & 12 \\
\hline Clitoria arborea & 5.00 & 20 & 0.87 & 0.59 & $\mathrm{VL}^{(8)}$ & $\mathrm{LO}^{(2)}$ & $\mathrm{LO}^{(2)}$ & 12 \\
\hline Libidibia ferrea & 7.32 & 41 & 0.57 & 0.54 & $\mathrm{VL}^{(8)}$ & $\mathrm{LO}^{(2)}$ & $\mathrm{LO}^{(2)}$ & 12 \\
\hline Cedrela fissilis & 13.04 & 23 & 0.85 & 0.57 & $\mathrm{VL}^{(8)}$ & $\mathrm{LO}^{(2)}$ & $\mathrm{LO}^{(2)}$ & 12 \\
\hline Guazuma ulmifolia & 20.00 & 5 & 1.20 & 0.81 & $\mathrm{LO}^{(6)}$ & $\mathrm{HI}^{(3)}$ & $\mathrm{HI}^{(3)}$ & 12 \\
\hline Mimosa schomburgkii & 28.57 & 7 & 1.73 & 0.74 & $\mathrm{LO}^{(6)}$ & $\mathrm{HI}^{(3)}$ & $\mathrm{HI}^{(3)}$ & 12 \\
\hline Machaerium froesii & 30.00 & 10 & 1.06 & 0.68 & $\mathrm{LO}^{(6)}$ & $\mathrm{HI}^{(3)}$ & $\mathrm{HI}^{(3)}$ & 12 \\
\hline Vismia guianensis & 16.67 & 108 & 1.02 & 1.11 & $\mathrm{LO}^{(6)}$ & $\mathrm{LO}^{(2)}$ & $\mathrm{HI}^{(2)}$ & 11 \\
\hline Guatteria punctate & 21.43 & 28 & 0.81 & 0.76 & $\mathrm{LO}^{(6)}$ & $\mathrm{LO}^{(2)}$ & $\mathrm{HI}^{(2)}$ & 11 \\
\hline Byrsonima crassifolia & 28.46 & 123 & 0.79 & 0.71 & $\mathrm{LO}^{(6)}$ & $\mathrm{LO}^{(2)}$ & $\mathrm{HI}^{(2)}$ & 11 \\
\hline Anacardium occidentale & 48.28 & 29 & 1.20 & 0.35 & $\mathrm{LO}^{(6)}$ & $\mathrm{HI}^{(3)}$ & $\mathrm{LO}^{(2)}$ & 11 \\
\hline Solanum fulvidum & 50.00 & 8 & 1.00 & 0.81 & $\mathrm{LO}^{(6)}$ & $\mathrm{LO}^{(2)}$ & $\mathrm{HI}^{(3)}$ & 11 \\
\hline Enterolobium schomburgkii & 15.00 & 20 & 0.97 & 0.55 & $\mathrm{LO}^{(6)}$ & $\mathrm{LO}^{(2)}$ & $\mathrm{LO}^{(2)}$ & 10 \\
\hline Chloroleucon acacioides & 20.00 & 10 & 0.83 & 0.53 & $\mathrm{LO}^{(6)}$ & $\mathrm{LO}^{(2)}$ & $\mathrm{LO}^{(2)}$ & 10 \\
\hline Pseudobombax munguba & 20.00 & 5 & 0.83 & 0.29 & $\mathrm{LO}^{(6)}$ & $\mathrm{LO}^{(2)}$ & $\mathrm{LO}^{(2)}$ & 10 \\
\hline Amburana cearensis & 20.00 & 5 & 0.46 & 0.35 & $\mathrm{LO}^{(6)}$ & $\mathrm{LO}^{(2)}$ & $\mathrm{LO}^{(2)}$ & 10 \\
\hline Hymenaea parvifolia & 29.67 & 91 & 0.76 & 0.43 & $\mathrm{LO}^{(6)}$ & $\mathrm{LO}^{(2)}$ & $\mathrm{LO}^{(2)}$ & 10 \\
\hline Genipa americana & 30.25 & 119 & 0.56 & 0.32 & $\mathrm{LO}^{(6)}$ & $\mathrm{LO}^{(2)}$ & $\mathrm{LO}^{(2)}$ & 10 \\
\hline Bauhinia rufa. & 32.00 & 25 & 0.71 & 0.40 & $\mathrm{LO}^{(6)}$ & $\mathrm{LO}^{(2)}$ & $\mathrm{LO}^{(2)}$ & 10 \\
\hline Chamaecrista ensiformis var. plurifoliolata & 33.33 & 12 & 0.71 & 0.49 & $\mathrm{LO}^{(6)}$ & $\mathrm{LO}^{(2)}$ & $\mathrm{LO}^{(2)}$ & 10 \\
\hline Lueheopsis duckeana & 33.33 & 9 & 0.92 & 0.40 & $\mathrm{LO}^{(6)}$ & $\mathrm{LO}^{(2)}$ & $\mathrm{LO}^{(2)}$ & 10 \\
\hline Pseudima frutescens & 36.36 & 11 & 0.57 & 0.35 & $\mathrm{LO}^{(6)}$ & $\mathrm{LO}^{(2)}$ & $\mathrm{LO}^{(2)}$ & 10 \\
\hline Oenocarpus distichus. & 37.50 & 8 & 0.93 & 0.24 & $\mathrm{LO}^{(6)}$ & $\mathrm{LO}^{(2)}$ & $\mathrm{LO}^{(2)}$ & 10 \\
\hline Handroanthus ochraceus & 38.10 & 21 & 0.85 & 0.44 & $\mathrm{LO}^{(6)}$ & $\mathrm{LO}^{(2)}$ & $\mathrm{LO}^{(2)}$ & 10 \\
\hline Andira inermis & 40.00 & 25 & 0.52 & 0.38 & $\mathrm{LO}^{(6)}$ & $\mathrm{LO}^{(2)}$ & $\mathrm{LO}^{(2)}$ & 10 \\
\hline Cordia goeldiana & 43.90 & 123 & 0.62 & 0.33 & $\mathrm{LO}^{(6)}$ & $\mathrm{LO}^{(2)}$ & $\mathrm{LO}^{(2)}$ & 10 \\
\hline Samanea tubulosa & 45.10 & 51 & 1.01 & 0.50 & $\mathrm{LO}^{(6)}$ & $\mathrm{LO}^{(2)}$ & $\mathrm{LO}^{(2)}$ & 10 \\
\hline Clitoria fairchildiana & 45.45 & 11 & 1.01 & 0.50 & $\mathrm{LO}^{(6)}$ & $\mathrm{LO}^{(2)}$ & $\mathrm{LO}^{(2)}$ & 10 \\
\hline Hevea brasiliensis & 47.37 & 19 & 0.45 & 0.34 & $\mathrm{LO}^{(6)}$ & $\mathrm{LO}^{(2)}$ & $\mathrm{LO}^{(2)}$ & 10 \\
\hline Cenostigma tocantinum & 50.00 & 20 & 0.55 & 0.41 & $\mathrm{LO}^{(6)}$ & $\mathrm{LO}^{(2)}$ & $\mathrm{LO}^{(2)}$ & 10 \\
\hline Swietenia macrophylla & 50.88 & 57 & 0.74 & 0.46 & $\mathrm{LO}^{(6)}$ & $\mathrm{LO}^{(2)}$ & $\mathrm{LO}^{(2)}$ & 10 \\
\hline Sapindus saponaria & 50.98 & 102 & 0.60 & 0.28 & $\mathrm{LO}^{(6)}$ & $\mathrm{LO}^{(2)}$ & $\mathrm{LO}^{(2)}$ & 10 \\
\hline
\end{tabular}

$L O=$ Low $; V L=$ Very low; $H I=$ High $; V H=$ Very high; $W V=$ Weighted value $;$ numbers in parentheses show the weight of each variable, where the sum for each species will result in the $W V$.

\section{CONCLUSIONS}

The mortality rate was low to very low for 35 of the 156 evaluated species, and the growth in diameter and height was low to very high, and thus are indicated as priorities for the initial planting in new areas in which the goal is to reestablish the native vegetation. In addition, the cost of new projects will decrease with the production of seedlings and replanting, further increasing the efficiency of the restoration, making it successful.

We noted that high mortality rates (> 75\%) for 21 species, forming a group of species which are not recommended for planting, at least in the implantation phase of the areas, while the survival rate for 32 species was higher than $60 \%$.

We recorded thirty-six (36) species in the spontaneous natural regeneration, three of which were recruited and the others entered the sample during the monitoring, namely: Solanum crinitum, Solanum sp., Trema micrantha, Vismia guianensis, and Croton matourensis were recorded in all the studied areas.

Six species are on official endangered species lists, with growth rates and mortality according to the criteria adopted in the study, and thus their maintenance and inclusion in new areas should 
be fostered as a strategy for enriching and conserving recovery areas. Another nine species are on exotic species lists in Brazil and four in the Amazon Biome, and their planting is not recommended for ecological restoration to avoid biological invasions in the future which might compromise the restoration objective.

\section{ACKNOWLEDGMENTS}

The Universidade Federal Rural da Amazônia (UFRA) and its field technicians during the activities. The Conselho Nacional de Desenvolvimento Científico e Tecnológico (CNPq) for granting a scholarship granted to the first author (141945/2019-2) and the Hydro through the Biodiversity Research Consortium Brazil-Norway (BRC). This article is number BRC0013 in the publication series of the Biodiversity Research Brazil-Norway.

\section{REFERENCES}

1. ABAL. Associação Brasileira de Alumínio. Bauxita no Brasil: mineração responsável e competitividade. São Paulo: ABAL, 2017. 66 p.

2. Alvares CA, Stape JL, Sentelhas PC, Gonçalves JLM, Sparovek G. Köppen's climate classification map for Brazil. Meteorol Z. 2013;22:711-728, doi:10.1127/0941-2948/2013/0507.

3. Atondo-Bueno EJ, Bonilla-Moheno M, López-Barrera F. Cost-efficiency analysis of seedling introduction vs. direct seeding of Oreomunnea mexicana for secondary forest enrichment. Forest Ecol Manage. 2018;409:399-346, doi:10.1016/j.foreco.2017.11.028.

4. Baur B. Dispersal-limited species - A challenge for ecological restoration. Basic Appl. Ecol. 2014;15:559564, doi:10.1016/j.baae.2014.06.004.

5. Byng JW, Chase MW, Christenhusz MJ, Fay MF, Judd WS, Mabberley DJ, Briggs B, Soltis DE, Sennikov AN, Soltis PS, Stevens PF. An update of the angiosperm phylogeny group classification for the orders and families of flowering plants: APG IV. Bot J Linn Soc. 2016;181:1-20, doi:10.1111/boj.12385.

6. Chazdon R. Regeneração de florestas tropicais. Bol Mus Emílio Goeldi. 2012;7:195-218.

7. DNPM. Departamento Nacional de Produção Mineral. Sumário Mineral. Brasília, 2015. 146 p.

8. Dudley N, Bhagwat SA, Harris J, Maginnis S, Moreno JG, Mueller GM, Oldfield S, Walters G. Measuring progress in status of land under forest landscape restoration using abiotic and biotic indicators. Restor Ecol. 2018;26:5-12, doi:10.1111/rec.12632.

9. Fengler FH, Bressane A, Carvalho MM, Longo RM, Medeiros GA, Melo WJ, Jacovac CC, Ribeiro AI. Forest restoration assessment in Brazilian Amazonia: A new clustering-based methodology considering the reference ecosystem. Ecol Eng. 2017;108:93-99, doi: 10.1016/j.ecoleng.2017.08.008.

10. Ferreira MC, Vieira DLM. Topsoil for restoration: Resprouting of root fragments and germination of pioneers triggers tropical dry forest regeneration. Ecol Eng. 2017;103:1-12, doi:10.1016/j.ecoleng.2017.03.006.

11. Fowler WM, Fontaine JB, Enright NJ, Veber WP. Evaluating restoration potential of transferred topsoil. Appl Veg Sci. 2015;18:529-558, doi:10.1111/avsc.12162.

12. Flora do Brasil 2020 em construção. Jardim Botânico do Rio de Janeiro. Disponível em: <http://floradobrasil.jbrj.gov.br/>. 18 Abr. 2019.

13. IBGE. Instituto Brasileiro de Geografa e Estatística. Manual técnico da vegetação brasileira. 2. ed. Rio de Janeiro. 2012. 275 p.

14. IUCN. International Union for Conservation of Nature. Disponível em: <https://www.iucn.org// >. 20 Dez. 2019.

15. Jardim FCS. Natural regeneration in tropical forests. Rev Ci Agr. 2015;58:105-113, doi:10.4322/rca.1676.

16. Jesus EM, Santos TS, Ribeiro GT, Orge MDR, Amorim VO, Batista RCRC. Regeneração natural de espécies vegetais em jazidas revegetadas. Florest Ambient. 2016;23:191-200, doi:10.1590/21798087.115914 .

17. Maia GN. Caatinga: árvores e arbustos e suas utilidades. São Paulo: D\&Z. Computação Gráfica, 2004. $413 \mathrm{p}$.

18. Martins WBR, Ferreira GC, Souza FP, Dionisio LFS, Oliveira FA. Deposição de serapilheira e nutrientes em áreas de mineração submetidas a métodos de restauração florestal em Paragominas, Pará. Floresta. 2018;48:37-48, doi:10.5380/rf.v48 i1.49288.

19. Martins WBR, Vale RL, Ferreira GC, Andrade VMS, Dionísio LFS, Rodrigues RP, Oliveira FA, Souza GMP. Litterfall, litter stock and water holding capacity in post-mining forest restoration ecosystems, Eastern Amazon. Rev Bras Ci Agr. 2018;13:1-9, doi:10.5039/agraria.v13i3a5546. 
20. Martinelli G, Moraes MA. Livro Vermelho da Flora do Brasil: Plantas raras do Cerrado. 1. ed. Rio de Janeiro: Instituto de Pesquisas Jardim Botânico do Rio de Janeiro: CNCFlora, 2014. 322 p.

21. Meli P, Isernhagen I, Brancalion PHS, Isernhagen ECC, Behling M, Rodrigues RR. Optimizing seeding density of fast-growing native trees for restoring the Brazilian Atlantic Forest. Rest Ecol. 2017;26:1-8, doi:10.1111/rec.12567.

22. Moraes LFD, Assumpção JM, Pereira TS, Luchiari C. Manual técnico para a restauração de áreas degradadas no Estado do Rio de Janeiro. Rio de Janeiro: Jardim Botânico, 2013. 84 p.

23. Nascimento GO, Pereira JAA, Barros DA, Silva RA, José AC, Ferreira JB, Oliveira SS. Propagule emergence in topsoil from a high-altitude field end implications for bauxite mining area restoration. Int $\mathrm{J}$ Biodivers Conserv. 2016;8:310-319, doi:10.5897/IJBC2016.1031.

24. Rai A, Singh AK, Ghosal N, Singh N. Understanding the effectiveness of litter from tropical dry forests for the restoration of degraded lands. Ecol Eng. 2016;93:76-81, doi:10.1016/j.ecoleng.2016.05.014.

25. Rodrigues TE, Silva RC, Silva JML, Oliveira Júnior RC, Gama JRN, Valente MA. Caracterização e classificação dos solos do município de Paragominas, Estado do Pará. Belém: Embrapa Amazônia Oriental, 2003. $51 \mathrm{p}$.

26. Salomão RP, Rosa NA, Morais KAC. Dinâmica da regeneração natural de árvores em áreas mineradas na Amazônia. Bol Mus Emílio Goeldi. 2007;2:85-139.

27. Salomão RP, Brienza-Júnior S, Rosa NA. Dinâmica de reflorestamento em áreas de restauração após mineração em unidade de conservação na Amazônia. Rev Arv. 2014;38:1-24, doi:10.1590/S010067622014000100001

28. Shimizu JY. Estratégia complementar para conservação de espécies florestais nativas: resgate e conservação de ecótipos ameaçados. Pesq Florest Bras. 2007;54:07-35.

29. Silva KA, Martins SV, Miranda Neto A, Demolinari RA, Lopes AT. Restauração florestal de uma mina de bauxita: avaliação do desenvolvimento das espécies arbóreas plantadas. Florest Ambient. 2016;23:309-319, doi:10.1590/2179-8087.142515.

30. Silva APM, Schweizer D, Marques HR, Teixeira AMC, Santos TVMN, Sambuichi RHR, Badari CG, Gaudare U, Brancalion PHS. Can current native tree seedling production and infrastructure meet an increasing forest restoration demand in Brazil? Rest Ecol. 2017;25:509-515, doi:10.1111/rec.12470.

31. Souza CR, Rossi LMB, Azevedo CP, Vieira AH. Paricá: Schizolobium parahyba var. amazonicum (Huber x Duck) Barney. Manaus: Embrapa Amazônia Oriental, 2003. 12 p.

32. Souza AL, Soares CPB. Florestas nativas: estrutura, dinâmica e ambiência. Viçosa: UFV, 2013. 322 p.

33. Villa EB, Pereira MG, Alonso JM, Beutler SJ, Leles PSS. Aporte de serapilheira e nutrientes em áreas de restauração florestal com diferentes espaçamentos de plantio. Florest Ambient. 2016;23:90-99, doi:10.1590/2179-8087.067513.

34. Villacís J, Armas C, Hang S, Casanoves F. Selection of adequate species for degraded areas by oilexploitation industry as a key factor for recovery forest in the Ecuadorian Amazon. L Degrad Dev. 2016;27:1771-1780, doi:10.1002/ldr.2511. 